\title{
Development of Alternatives to Mitigate Deterioration of Segara Anakan Lagoon as Revealed by Analytical Hierarchy Process
}

\author{
Harnita Rosalina \\ Large River Basin Organization of Citanduy, Ministry of Public Works and Houses, Banjar, INDONESIA \\ harnitarose@gmail.com
}

\begin{abstract}
Segara Anakan is a lagoon located in estuary area of Citanduy and Cibeureum rivers. The main problem that exists in the region Segara Anakan is a shrinking area of Segara Anakan lead lagoon function becomes ineffective due to the increased volume of sediment in estuaries Citanduy. Refinement Segara Anakan will impact annual floods that occurred in the area downstream Citanduy. Have far-reaching is the decline in fish production, which makes the source of livelihood for the community residents of Kampung Laut, furthermore, the environmental changes that occurred in the area Segara Anakan have resulted in shrinking coastal fisheries resources and the expansion of land arising from silting. Assessment of the problem conducted by the method of approach of Analytical Hierarchy Process (AHP) to obtain the best alternatives among three alternatives being offered to sustain the function of Segara Anakan Lagoon. These three alternatives include the 1) Dredging the Lagoon and Upstream Watershed Conservation; 2) Dredging the Lagoon and Reclamation Work around Segara Anakan, and 3) Dredging the Lagoon and Citanduy Diversion. Some criteria and sub-criteria are adapted to support the selection of the alternatives and related questionnaires were developed, and the questionnaire filling was carried out through the implementation of Focus Group of Discussion or FGD. The criteria include several aspects of the criteria and sub-criteria are technical (floods, silting), socioeconomic (the tourist area, the local economy), as well as the environment (fisheries/shipping, agriculture and mangrove forests). Results of the analysis applying the AHP method showed the consistent value on the Alternative 3), i.e. the Dredging of the Lagoon and the Upstream Watershed Conservation (38\%).
\end{abstract}

Keywords: Segara Anakan, Analytical Hierarchy Process, estuary sedimentation

\section{INTRODUCTION}

The main river of Citanduy River Basin is the Citanduy River which flows through two provinces, i.e. West Java Province and Central Java Province. The upstream part of Citanduy River Basin is mountainous area of Mt. Cakrabuana at Tasikmalaya District, whereas the downstream part is an estuary at Segara Anakan Lagoon of Cilacap District.

The main problem that appears in area of Segara Anakan is the decrease of the lagoon area that causes ineffective function due to the increased volume of sedimentation in the estuary of Citanduy River (Supraharmonia, 2014). Sedimentation of Segara Anakan will potentially increase annual flood at downstream area of Citanduy River. However, the sedimentation may give advantage to the people in area of Segara Anakan, especially at Kampung Laut. They use sedimentation in the estuary of Cimeneng River as farming area (Rosalina, 2016).

Mitigation of flood in the downstream area of Segara Anakan can be conducted by Analytic Hierarchy Process (AHP) method for decision-making process which is based on several alternatives, e.g. dredging at the Lagoon and conservation of upstream watershed; dredging and reclamation at Segara Anakan area; and dredging at the Lagoon and shunt of Citanduy. This research is performed to give input to the Government Policy regarding the conservation plan of Segara Anakan Lagoon.

\section{LITERATURE REVIEW}

The AHP may give solution to some complex problems with various aspects and criteria. The previous research of Pertanto (2006) used AHP method as an approach methodology in irrigation water allocation by considering the 4 alternatives and 3 criteria. According to Saaty (1981), AHP can be used for decision making, which is designed and conducted rationally with a good selection on alternatives that already evaluated in multi criteria. During the process, the Decision maker produces a slightly difference result and develops all the priorities in order to make priority rank of several alternatives. In AHP, there is Consistent Decision and Inconsistent Decision (Pertanto, 2006)

According to the problems at Segara Anakan area, AHP can be used as a mitigation effort for physical 
disaster and social conflict that may arise with rational approach to select the best alternatives of problem solving which will be evaluated in multi criteria.

Comparative judgment, as it is mentioned in the research of Universitas Sumatera Utara (2011), is conducted by relative interest scoring of two elements in certain level that is related to the upper level. Assessment is the core of AHP since it has significant influence to the priority rank of elements. The assessment result will be much easier to be shown in the form of matrix pairwise comparisons i.e. a pair of comparison matrix that has alternative preference level for each criterion. The preference scale of Saaty (1981) uses scale 1 as the lower level (equal importance), to scale 9 as the highest level (extreme importance).

\section{RESEARCH METHODOLOGY}

\subsection{Location Study}

Several villages in Segara Anakan area are chosen to become the research area, i.e. Village of Bagolo, Pamotan, Rawa Apu, and Ujung Gagak, as shown in Figure 1.

\subsection{Research Stages}

The first stage of the research was a preparation, which was performed in the following steps: a) Literature study, to collect and study literature and theories that are relevant to the research;

b) Collecting primary data which consist of respondent data, field survey, interview, and give questionnaire to the respondents;

c) Collecting secondary data from related Institutions, population data per District, and Maps that relevant to the research;

d) Data analysis which consists of scoring analysis on questionnaire result and analysis of AHP method.

The research stages are summarized in a Flowchart, as it is shown in Figure 2.

\subsection{Three Diagram of AHP}

The physical and social problem-solving at Segara Anakan Lagoon needs to be conducted in decomposition hierarchy structure method to obtain decision which will be the priority. The tree diagram of AHP can be seen in Figure 3.

\subsection{Discussion}

Several problems will be discussed in this research, i.e. determination of respondent by distribution of variables, how to fill and analyze the questionnaire, and decision making process with AHP method.
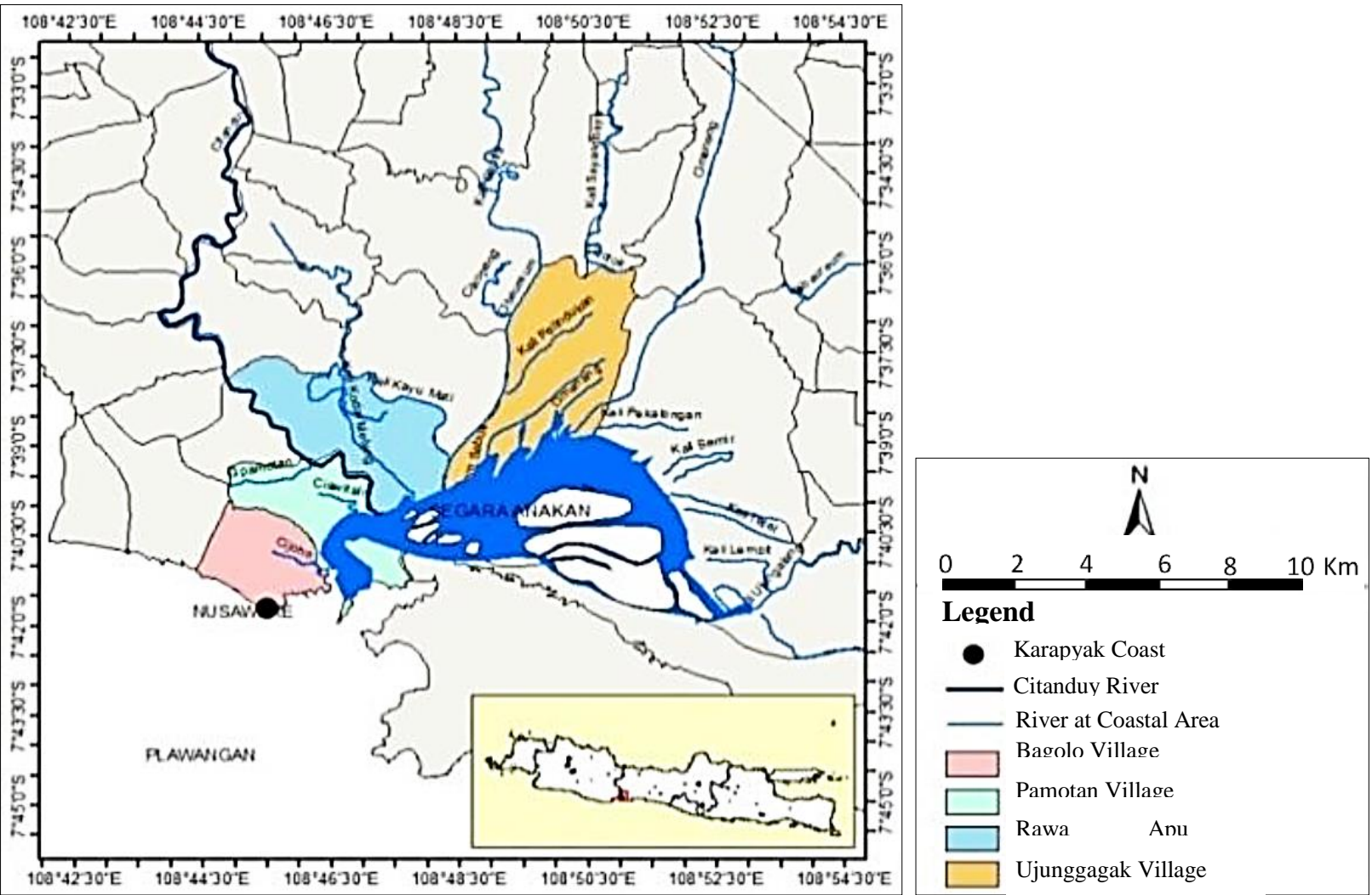

Figure 1. Map of Research Area 


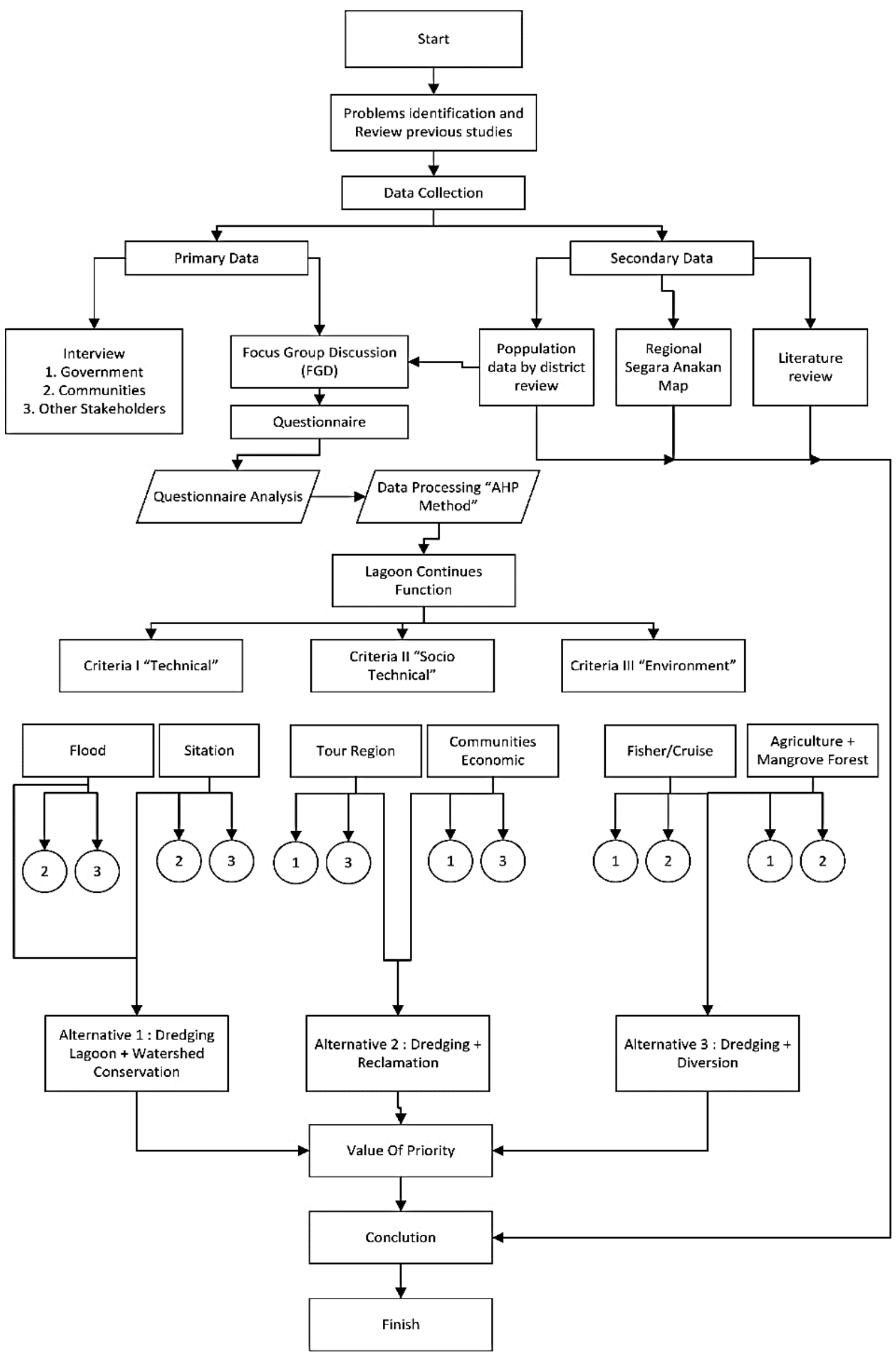

Figure 2. Flowchart of research implementation. 


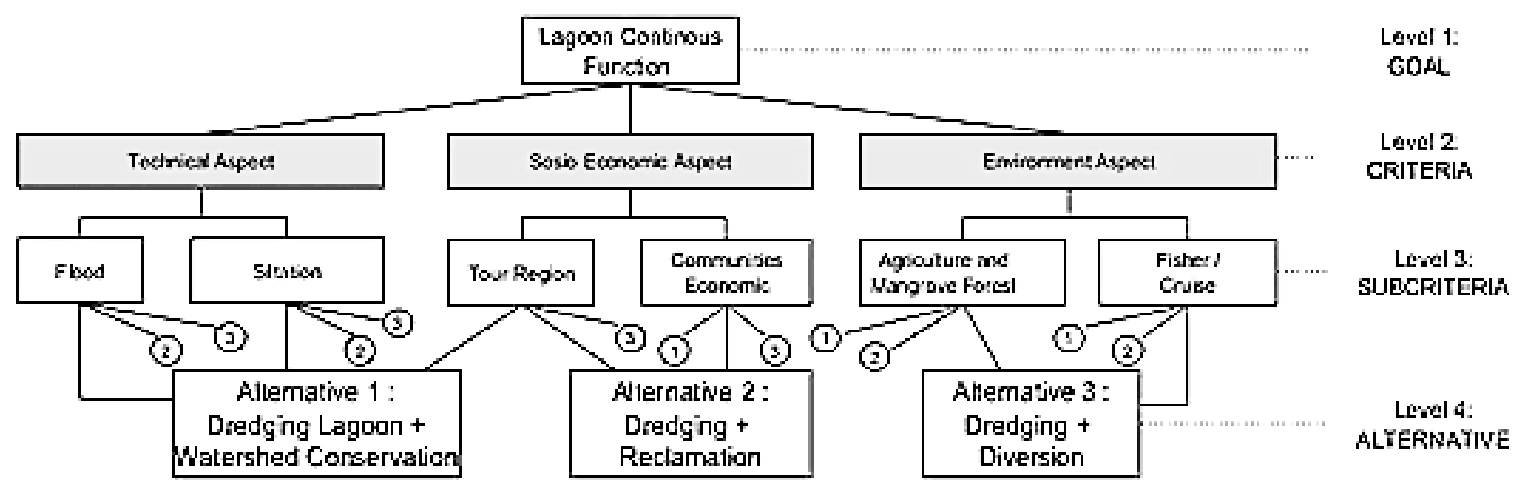

Figure 3. Three diagrams of AHP

The research variable is determined by several people as respondents, which consist of :

a) Variable of interest groups, with several attributes, i.e. governments, communities, and other stakeholders.

b) Variable of age, with attributes $>35$ years old dan $<35$ years old. In considering that the group age of $>35$ years old has broader knowledge.

c) Variable of insight and knowledge, with attribute of not involved (inexperienced) and attribute of involved (experienced) into Segara Anakan environment.

d) All Variable, with attribute from all respondents.

Analysis of questionnaire in this research is conducted in the following steps :

a) Separating and determining score and questionnaire validity based on variable of group/interest of each respondent.

b) Making list of respondent from all respondent of the first step.

Table 1. Range of AHP criteria scale of questionnaire score/value c) Making range or value of each respondent based on the questionnaire result and producing table of criteria level. Table of interest range based on questionnaire score/value is shown in Table 1.

d) Making different choices of two interests that were derived from the third step, as it is shown in Table 2 and Table 3.

e) Assessment of level also takes the opinion directly drawn from the respondent into consideration, not only based on questionnaire score.

f) A respondent with value of 1 in the questionnaire has not taken into consideration in the calculation.

g) There is also consideration, on some occasion, where value of 1 will be calculated.

h) The next step is following the 1st step, which is creating groups based on age, knowledge, and mixed variable.

i) Test of consistency ratio value of pairwise comparison matrix result, if the $\mathrm{CR}<0.1$. When the $\mathrm{CR}$ result is inconsistent, thus the calculation result need to be repeated or there should be a reason to show that it is inconsistent (Singarimbun, 1987; Handayani, 1987).

\begin{tabular}{llllll}
\hline Parameter & \multicolumn{4}{l}{ Scale of AHP from values questionnaire } & \\
\cline { 2 - 6 } & Do not know & Strongly disagree & Disagree & Agree & Strongly agree \\
\hline Siltation & $1-3$ & $4-6$ & $7-9$ & $10-12$ & $13-15$ \\
Flood & $1-3$ & $4-6$ & $7-9$ & $10-12$ & $13-15$ \\
Economic Society & $1-3$ & $4-6$ & $7-9$ & $10-12$ & $13-15$ \\
Tour Region & $1-3$ & $4-6$ & $7-9$ & $10-12$ & $13-15$ \\
Agriculture + forest & $1-3$ & $4-6$ & $7-9$ & $10-12$ & $13-15$ \\
Fishery/Cruise & $1-3$ & $4-6$ & $7-9$ & $10-12$ & $13-15$ \\
Technical, Social, Environment & $1-5$ & $6-10$ & $11-15$ & $16-20$ & $21-25$ \\
\hline
\end{tabular}

Table 2. Table of different value of average of average interest scale criteria

\begin{tabular}{ccccc}
\hline Equally important & Some more important & Quite important & Very important & Absolute more important \\
\hline 0 & $0.1-0.9$ & $1-1.9$ & $2-2.9$ & $3-4$ \\
\hline
\end{tabular}

Table 3. Table of different value of sub criteria interest scale

\begin{tabular}{ccccc}
\hline Equally important & Some more important & Quite important & Very important & Absolute more important \\
\hline 0 & 1 & 2 & 3 & 4 \\
\hline
\end{tabular}




\section{RESULT AND DISCUSSION}

\subsection{List of Respondents Research}

There are 95 respondents in this research (see Table 4).

Table 4. Number of respondents research

\begin{tabular}{lccc}
\hline \multirow{2}{*}{ Group } & Insight / Knowledge & \multirow{2}{*}{ Number of Respondents } \\
\cline { 2 - 3 } & No Experience & Experience & 17 \\
\hline Government & 9 persons & 8 persons & 62 \\
Communities & 36 persons & 26 persons & 16 \\
Other Stakeholders & 6 persons & 10 persons & 95 \\
Total & 51 persons & 44 persons & \\
\hline
\end{tabular}

\subsection{Focus Group Discussion and Completion of Questionnaires}

The Focus Group Discussion (FGD) and questionnaire survey were conducted in villages in the research area, as it is shown

Table 5. FGD Location and schedule of implementation

\begin{tabular}{|c|c|c|c|c|c|c|}
\hline No & FGD Location & $\begin{array}{l}\text { Number of } \\
\text { participants }\end{array}$ & $\begin{array}{l}\text { Number of } \\
\text { respondents }\end{array}$ & Population & $\%$ & Date \\
\hline 1 & $\begin{array}{l}\text { Ujung Gagak Village, Kampung Laut } \\
\text { District, Cilacap Regency }\end{array}$ & 21 & 19 & 4,861 & 0.39 & $\begin{array}{l}\text { Monday, } \\
18 \text { April } 2016\end{array}$ \\
\hline 2 & $\begin{array}{l}\text { Rawa Apu Village, Patimuan District, } \\
\text { Cilacap Regency }\end{array}$ & 11 & 11 & 8,886 & 0.12 & $\begin{array}{l}\text { Wednesday, } 20 \\
\text { April } 2016\end{array}$ \\
\hline 3 & $\begin{array}{l}\text { Pamotan Village, Kalipucang District, } \\
\text { Pangandaran Regency }\end{array}$ & 19 & 19 & 4,852 & 0.39 & $\begin{array}{l}\text { Friday, } 22 \\
\text { April } 2016\end{array}$ \\
\hline 4 & $\begin{array}{l}\text { Bagolo Village, Kalipucang District, } \\
\text { Pangandaran Regency }\end{array}$ & 13 & 13 & 3,123 & 0.42 & $\begin{array}{l}\text { Monday, } \\
25 \text { April } 2016\end{array}$ \\
\hline
\end{tabular}

The questionnaire scoring results can be described as follows:

a) Scoring based on total score of each aspect or criteria (see Table 7).

b) Scoring based on total score of each parameter or sub criteria (see Table 8).

c) Produce score from comparison table to get comparison matrix of each criterion and/or sub criteria (see Table 9).

d) Produce score from comparison table to get comparison matrix of each alternative from each criterion and/or sub criteria (see Table 10).

The value of questionnaire result of all respondents is shown in Table 6

\subsection{Data of Respondent Consistency Test}

Each variable shows consistency ratio less than 0.1, which means the result is inconsistent. Several questionnaire scoring and opinion of respondents show inconsistent value. There are several factors that may cause inconsistent on the result, e.g.:

a) There is no feasibility test on the questionnaire and its analysis on some example respondent.

b) The misunderstanding of respondent on the meaning of questionnaire and the main problem.

c) Unequal number of respondent on each variable.

d) Impropriety or mismatch on the experience and profession of respondent that is related to the problems mentioned in the questionnaire.

e) The instrument is confusing and not related to the respondent.

f) There is more choices or comparator, thus there is also bigger chance to have inconsistent result.

g) The available score is not suitable with respondent opinion, which tends to give inconsistent result. 
Table 6. Questionnaire scoring result

\begin{tabular}{|c|c|c|c|c|c|}
\hline \multicolumn{2}{|l|}{ Group Variable } & Government & Communities & Other Stakeholders & Total \\
\hline \multicolumn{2}{|c|}{ Number of Respondents (persons) } & 17 & 62 & 16 & 95 \\
\hline \multirow{4}{*}{ Technical Aspects } & Dredging + Watershed Conservation & 329 & 1210 & 305 & 1844 \\
\hline & Dredging + Reclamation & 284 & 1054 & 262 & 1600 \\
\hline & Dredging + Citanduy Diversion & 298 & 1136 & 271 & 1705 \\
\hline & Dredging + Watershed Conservation & 275 & 1065 & 273 & 1613 \\
\hline \multirow{3}{*}{$\begin{array}{l}\text { Sosio Economic } \\
\text { Aspects }\end{array}$} & Dredging + Reclamation & 310 & 1189 & 262 & 1761 \\
\hline & Dredging + Citanduy Diversion & 286 & 1137 & 274 & 1697 \\
\hline & Dredging + Watershed Conservation & 297 & 1101 & 284 & 1682 \\
\hline \multirow{3}{*}{$\begin{array}{l}\text { Environment } \\
\text { Aspects }\end{array}$} & Dredging + Reclamation & 306 & 1120 & 269 & 1695 \\
\hline & Dredging + Citanduy Diversion & 272 & 1077 & 276 & 1625 \\
\hline & Dredging + Watershed Conservation & 901 & 3376 & 862 & 5139 \\
\hline \multirow[t]{2}{*}{ Total Aspect } & Dredging + Reclamation & 900 & 3363 & 793 & 5056 \\
\hline & Dredging + Citanduy Diversion & 856 & 3350 & 821 & 5027 \\
\hline
\end{tabular}

Table 7. Questionnaire scoring on criteria of government group variable

\begin{tabular}{|c|c|c|c|c|c|c|c|c|c|c|c|c|c|}
\hline \multirow{3}{*}{ No } & \multirow{3}{*}{ Name } & \multicolumn{12}{|c|}{ Result of the questionnaire } \\
\hline & & \multicolumn{4}{|c|}{ Technical } & \multicolumn{4}{|c|}{ Socio economic } & \multicolumn{4}{|c|}{ Environment } \\
\hline & & $\mathrm{A}$ & $\mathrm{B}$ & $\mathrm{C}$ & Average & $\mathrm{A}$ & B & $\mathrm{C}$ & Average & $\mathrm{A}$ & $\mathrm{B}$ & $\mathrm{C}$ & Average \\
\hline 1 & $\begin{array}{l}\text { Achmad } \\
\text { Chumaidi }\end{array}$ & 20 & 17 & 17 & 18 & 17 & 20 & 18 & 18.33 & 19 & 20 & 20 & 19.67 \\
\hline 2 & Daddy Moerhadio & 21 & 19 & 20 & 20 & 17 & 21 & 21 & 19.67 & 18 & 19 & 21 & 19.33 \\
\hline 3 & Agus Tri Wibowo & 20 & 19 & 19 & 19.33 & 21 & 17 & 19 & 19 & 19 & 18 & 19 & 18.67 \\
\hline 4 & Edwin Martha P & 21 & 20 & 19 & 20 & 18 & 19 & 17 & 18 & 18 & 19 & 18 & 18.33 \\
\hline 5 & Bagus Prio Utomo & 19 & 18 & 18 & 18.33 & 20 & 19 & 18 & 19 & 19 & 18 & 17 & 18 \\
\hline
\end{tabular}

Inquiries
A: Dredging Lagoon and Upstream Watershed Conservation
B: Dredging and Reclamation
C: Dredging and Citanduy Diversion

Table 8. Questionnaire scoring on sub criteria of government group variable

\begin{tabular}{|c|c|c|c|c|c|c|c|}
\hline \multirow{3}{*}{ No } & \multirow{3}{*}{ Name } & \multicolumn{6}{|c|}{ Sub Criteria } \\
\hline & & Siltation & Flood & Economic society & Tour region & $\begin{array}{l}\text { Agriculture + } \\
\text { forest }\end{array}$ & Fishery/cruise \\
\hline & & Score & Score & Score & Score & Score & Score \\
\hline 1 & Achmad Chumaidi & 12 & 10 & 12 & 11 & 12 & 12 \\
\hline 2 & Daddy Moerhadio & 13 & 13 & 15 & 13 & 13 & 12 \\
\hline 3 & Agus Tri Wibowo & 11 & 12 & 12 & 11 & 13 & 11 \\
\hline 4 & Edwin Martha $\mathrm{P}$ & 12 & 13 & 12 & 11 & 12 & 11 \\
\hline 5 & Bagus Prio Utomo & 12 & 10 & 12 & 11 & 11 & 11 \\
\hline 6 & Suhada & 11 & 10 & 12 & 11 & 13 & 9 \\
\hline
\end{tabular}

Table 9. Comparison pairwase matrix of each sub criteria

\begin{tabular}{|c|c|c|c|c|c|c|c|c|}
\hline & Flood & Siltation & $\begin{array}{l}\text { Tour } \\
\text { region }\end{array}$ & $\begin{array}{l}\text { Economic } \\
\text { society }\end{array}$ & Fishery/cruise & $\begin{array}{l}\text { Agriculture + } \\
\text { forest }\end{array}$ & Total & $\begin{array}{l}\text { Weight } \\
\text { priority }\end{array}$ \\
\hline Flood & 1 & 1.053 & 1.154 & 0.821 & 0.904 & 0.931 & 5.863 & 0.151 \\
\hline Siltation & 0.95 & 1 & 1.889 & 1.439 & 1.036 & 1.207 & 7.521 & 0.194 \\
\hline Tour Region & 0.867 & 0.529 & 1 & 0.488 & 0.8 & 0.486 & 4.17 & 0.108 \\
\hline Sosio Economic & 1.218 & 0.695 & 2.048 & 1 & 2 & 1.933 & 8.894 & 0.23 \\
\hline Fishery/cruise & 1.106 & 0.965 & 1.25 & 0.5 & 1 & 1.059 & 5.88 & 0.152 \\
\hline $\begin{array}{l}\text { Agriculture + } \\
\text { forest }\end{array}$ & 1.074 & 0.828 & 2.056 & 0.517 & 0.944 & 1 & 6.419 & 0.166 \\
\hline \multicolumn{7}{|c|}{ Total } & 38.747 & 1.00 \\
\hline
\end{tabular}


Table 10. Comparison pairwise matrix of each alternative based on technical criteria

\begin{tabular}{lcccccc}
\hline Method & $\begin{array}{l}\text { Dredging }+ \\
\text { Watershed } \\
\text { Conservation }\end{array}$ & $\begin{array}{l}\text { Dredging }+ \\
\text { Reclamation }\end{array}$ & $\begin{array}{l}\text { Dredging }+ \\
\text { Cit.Diversion }\end{array}$ & Total & $\begin{array}{l}\text { Weight } \\
\text { Priority }\end{array}$ & $\begin{array}{l}\text { Eigen } \\
\text { Vector' }\end{array}$ \\
\hline Dredging + Watershed & 1 & 1.56 & 1.08 & 3.64 & 0.39 & 0.39 \\
Conservation & 0.64 & 1 & 0.68 & 2.32 & 0.25 & 0.25 \\
Dredging + Reclamation & 0.93 & 1.48 & 1 & 3.41 & 0.36 & 0.36 \\
Dredging + Cit.Diversion & Total & & & 9.37 & 1 \\
\hline
\end{tabular}

Table 11. Table of Percentage Alternative Priority based on 6 Subcriteria

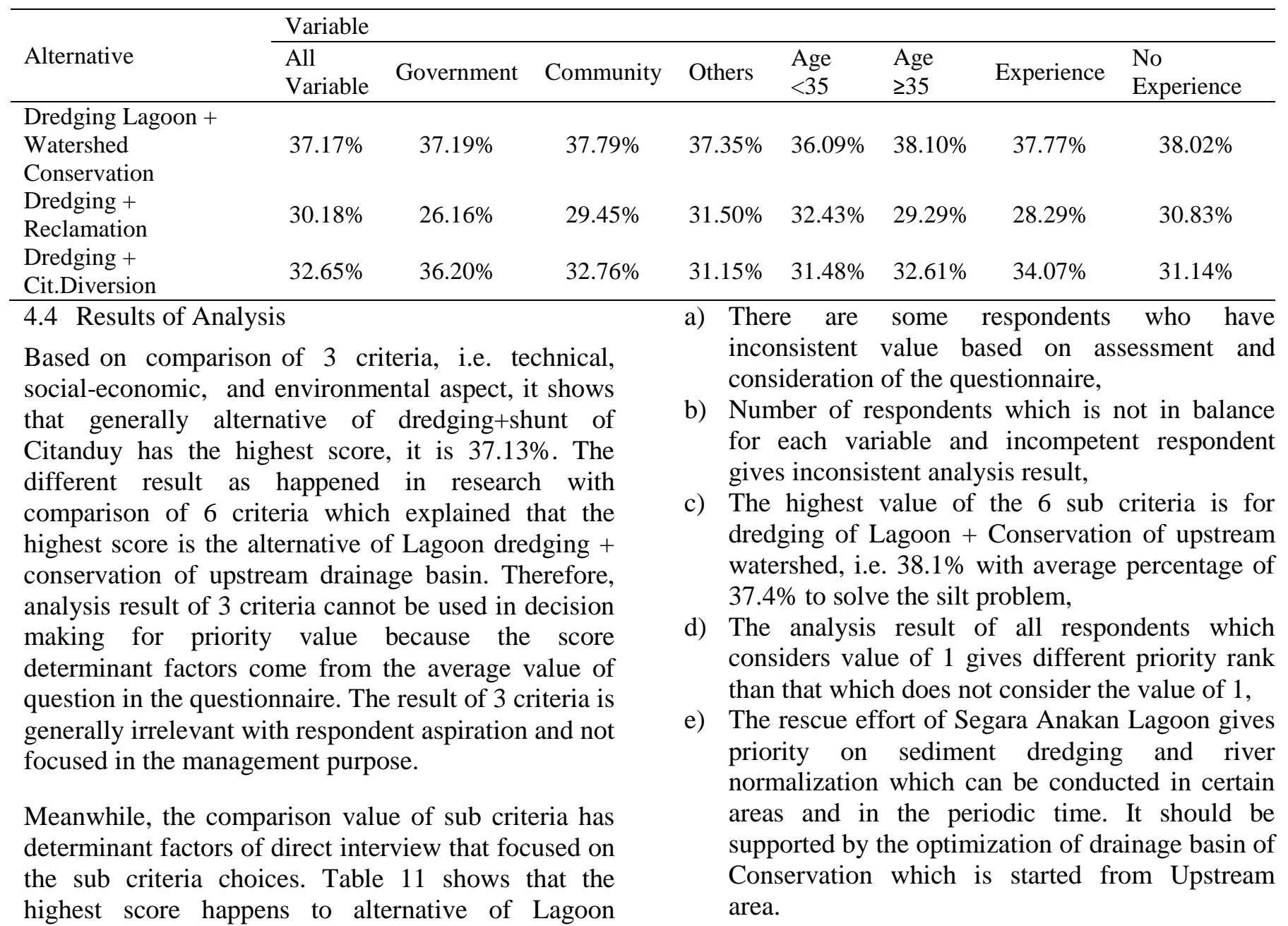
dredging and Conservation of upstream drainage basin, i.e. $38.1 \%$, and average percentage is $37.4 \%$. The result describes effort on Segara Anakan Lagoon conservation that might be performed by sediment dredging in the Lagoon, also river normalization along the Segara Anakan area, which is conducted periodically and they are divided into several dredging areas that are supported by optimization on drainage basin of Conservation area. The plan will start at Upstream area.

\section{CONCLUSIONS AND RECOMMENDATIONS}

\subsection{Conclusions}

The research results can be concluded as follows:

\subsection{Recommendations}

Based on the obstacle during research, there are several recommendations that can be suggested as follows:

a) Prior to questionnaire distribution and value determination, feasibility test of questionnaire needs to be conducted towards some respondents and the analysis,

b) Type of questions in the questionnaire should be comprehensible by respondent to avoid confusion,

c) Each respondent should be clearly directed before they start to fill the questionnaire to avoid misunderstanding and inconsistency, 
d) The inconsistency ratio of more than 0.1 needs to be clarified to respondents on their interest value choice.

\section{ACKNOWLEDGEMENTS}

The author would like to express her thanks and gratitude's to the Ministry of Public Works for the provision of chance and facilities those have been given to the author until this research is completed, and to the community villages for the survey implementation.

\section{REFERENCES}

Handayani, T., 1987. Pembuatan Kuisioner [Make a Questionnaire]. In: Metode Penelitian Survai. Yogyakarta: LP3 ES, pp. 175-187.

Pertanto, N., 2006. Pengalokasian Air Irigasi dengan Analytical Hierarchy Process (AHP). Studi Kasus : Saluran Induk Colo Timur di Wilayah Sragen ed. Yogyakarta: Universitas Gadjah Mada.

Rosalina, H., 2016. Pemilihan Alternatif Penyelamatan Laguna Segara Anakan Dengan
Metode Analytical Hierarchy Process [Alternatives for Conserving Segara Anakan Lagoon using Analytical Hierarchy Process], Yogyakarta: Master Thesis, Universitas Gadjah Mada.

Saaty, T. L., 1981. Decision Making for Leaders - The Analytical Hierarchy Process For Decisions in a Complex World. Pittsburgh: RWS Publications.

Singarimbun, M., 1987. Metode dan Proses Penelitian [Method and Research Process]. In: Metode Penelitian Survai . Yogyakarta: LPS ES, pp. 1-13.

Supraharmonia, P. C., 2014. Laporan Akhir Kajian Penanganan Sedimentasi Segara Anakan [Final Report of Sediment Management Study in Segara Anakan], Banjar: Balai Besar Wilayah Sungai Citanduy.

Universitas Sumater Utara, 2011. Institutional Repository Open Source. [Online] Available at: http://repository.usu.ac.id/bitstream/123456789/20560 13/Chapter\%20II.pdf

[Accessed 23 November 2015]. 